\title{
Chick Embryo Pancreatic Transplants Reverse Experimental Diabetes of Rats
}

\author{
R. Eloy, K. HAFFen, M. Kedinger, and J. F. Grenier, Unit 61, Institut National \\ de la Santé et de la Recherche Médicale, Strasbourg-Hautepierre, 67200 France
}

\begin{abstract}
A в S TRACT The effectiveness of xenogeneic embryonic tissue in the treatment of experimental diabetes has been investigated in rats. The splenic lobes (80) of 15- to 18-d-old chick embryos, composed almost exclusively of endocrine tissue, were implanted directly into the hepatic parenchyma of the rat recipient. The biochemical and metabolic changes in the recipients suggest that embryonic transplants of 15-d-old chick pancreases were able to significantly improve, for a prolonged period of time $(18 \mathrm{mo})$, the diabetic state of nonimmunosuppressed rats. None of the recipients of 18-d-old embryos splenic lobes exhibited a long-term improvement of the diabetic state after transplantation. The complete destruction of the pancreatic B cells of the recipients was asssessed by: $(a)$ immunocytochemical investigations of the recipient's pancreas, $(b)$ measurement of insulin in the liver and pancreas of the recipients and $(c)$ in situ vascular perfusion of their pancreas submitted to high glucose challenge. The results suggest that pancreatic tissue of the 15-d-old embryos is immunologically immature lacking one or several lymphocyte subsets implicated in the afferent loop of "non-self" recognition.
\end{abstract}

\section{INTRODUCTION}

At present, studies on the treatment of insulin-deficient diabetes mellitus have focused both on insulin replacement by islet transplantation and on glucagon suppression (1). Encouraging results have been obtained by transplanting isolated pancreatic islets into the peritoneal cavity with partial alleviation of the diabetic state $(2,3)$, by injecting islets into the portal vein followed by a complete reversal of diabetes (4), or by implanting them directly into the liver (5). Isogeneic transplanted islets have remained functioning for $>15$ mo (5).

Portions of this work were presented at the Surgical Research Society Meeting, London, January 1978, and at the VII International Congress of the Transplantation Society, Rome, September 1978.

Received for publication 6 April 1978 and in revised form 21 February 1979.
In contrast, islet allografts have not reversed hyperglycemia and long-term survival of the allografts has been difficult to achieve in rats with experimental diabetes. Allogeneic islets transplanted across the major histocompatibility locus of the rat, $\mathrm{AgB}$, have all been rejected rapidly, functioning for only $2-6 \mathrm{~d}$ $(6,7)$ and immunosuppression by agents such as azathioprine and methyl prednisolone have not been very helpful $(8 ; 9)$. Pretreatment of the recipient with donor liver extract and pertussis followed by a short course of antilymphocyte serum treatment has resulted in a much better overall survival of functioning islet allotransplants and the mean survival time \pm SEM was $37.7 \pm 18.9 \mathrm{~d}(10)$. In a previous study, in vitro culture before transplantation has been associated with prolonged survival of allogeneic islets across strongly histoincompatible barriers (11).

Apart from immunological incompatibility, other technical problems arise. Current techniques to isolate islets from the adult pancreas (collagenase digestion followed by either density gradient separation or handpicking of islets under a dissecting microscope) are laborious and lose a considerable number of islets. In addition, even in rodents, the techniques are not fully efficient because several adult donor rats are required to provide sufficient islet tissue for the suppression of the diabetic state of only one recipient. Difficulties increase even more when one attempts to isolate islets from the compact adult human pancreas and the yield is variable and unpredictable (12). Thus, the problems of isolating large numbers of viable islets as well as the requirement for a more effective immunosuppressive therapy still remain unsolved.

Theoretically, fetal islets might be preferable for transplantation because they could possibly have several advantages over adult islets: $(a)$ in some situations fetal tissue is clearly less antigenic than the corresponding adult tissue $(13,14) ;(b)$ fetal islets might have more potential for growth after transplantation $(15,16)$; and (c) a period of ischemia might be better tolerated by fetal than adult islet tissue.

In fact blood sugar levels were completely or partially controlled up to $165 \mathrm{~d}$ in diabetic syngeneic recipient 
rats using one to three fetal rat pancreases $(17,18)$. However, with homografts of fetal and(or) neonatal rat pancreas, a transitory reversal of diabetes was generally observed but symptoms returned in 2 or 3 wk with the rejection of the transplants (19). Only $20 \%$ of the recipients of fetal homografts were considered as successful without evidence of rejection in the study reported by Gonet and Renold (20). In a more recent study, 7 out of 10 allogeneic transplants were surviving 2 mo after implantation in nonimmunosuppressed histoincompatible recipients $(21)$.

There has been little experimental work on pancreatic islet cell xenografts but it has been reported that islet allografts and xenografts have similar morphologic and functional survival in non immunosuppressed diabetic rats and mice (22-24). Because human diabetics are treated with xenogeneic insulin, and because the chick embryonic pancreas provides a relatively pure source of endocrine tissue, the effectiveness of this xenogeneic embryonic tissue in experimental diabetes was investigated in this study. The splenic lobes of chick embryos were implanted directly into the hepatic parenchyma of the rat recipient because the liver may represent an immunologically privileged site $(25-27)$.

\section{METHODS}

Diabetes was induced in inbred male rats of the Lewis strain (Centre de Sélection et d'Elevage d'Animaux de Laboratoire, Orléans, France), weighing between 150 and $200 \mathrm{~g}$ by intravenous injection of Streptozotocin (Upjohn Co., Kalamazoo, Mich.). Doses of $65-70 \mathrm{mg} / \mathrm{kg}$ of body weight induced diabetes in $80-100 \%$ of rats resulting in nonfasting glucose levels of $5 \mathrm{~g} /$ liter during the 1 st $\mathrm{wk}$ after injection. After injection, animals were kept in individual metabolic cages throughout the experimental period. Animals were allowed to eat and drink ad libitum.

Transplantation of embyronic endocrine pancreas was performed $21 \mathrm{~d}$ after the induction of diabetes, in those animals in which fasting plasma glucose levels were above $2.5 \mathrm{~g} /$ liter on three determinations over the $3 \mathrm{wk}$ before transplantation.

Preparation of embryonic pancreatic transplants. White Leghorn eggs were incubated at $38.5^{\circ} \mathrm{C}$ for 15 and $18 \mathrm{~d}$. At each developmental stage, the splenic lobe of the pancreas (Fig. 1) was carefully dissected from surrounding tissue and stored until transplantation in humidified Falcon organ culture dishes (Falcon Labware, Div. of Becton, Dickinson \& Co., Oxnard, Calif.) on culture medium CMRL 1066 gelated by agar-agar. The splenic lobes of either 15- to 18-d-old embryos were used as transplants.

Transplantation method. After routine preparation under ether anesthesia, the abdomen of the recipient was entered through a midline incision and the anterior hepatic lobe was exposed. With fine forceps, small holes were drilled into the anterior hepatic lobe, into which the solid tissue grafts were placed; 70-80 embryonic splenic lobes were inserted and distributed within the parenchyma of the anterior lobe. The procedure took about 15-20 min and did not cause complications. No antibiotic and no insulin was given postoperatively. No immunosuppressive therapy was administered.

Metabolic and chemical analyses. The insulin content of the chicken pancreases was determined according to the tech-

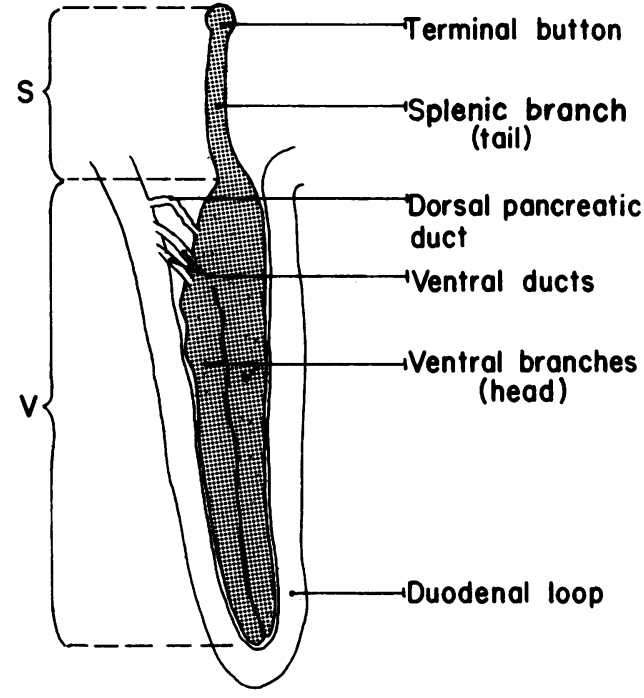

FIGURE 1 Splenic (S) and ventral (V) lobes of the pancreas in the chick embryo.

nique previously described (28). Acid-alcoholic extracts were dissolved in $0.04 \mathrm{M}$ phosphate buffer, $\mathrm{pH} 7.4$, with $0.002 \%$ merthiolate, $0.2 \%$ human albumin, and $0.6 \%$ saline. After several trials, one guinea pig antiserum against pig insulin was selected because of its high affinity for chick embryo insulin. In this study, chicken insulin was used as a standard.

The progress of the animals was followed by determination of: $(a)$ body weight (expressed as a percentage of the weight at the time of induction of the diabetic state); (b) daily urinary volume and glucose content; and $(c)$ twice weekly plasma fasting and nonfasting glucose and insulin concentrations. Serum glucose was measured on tail vein blood samples of ether anesthetized rats by the microanalytic glucose oxidase technique. Plasma immunoreactive insulin was measured by radioimmunoassay $(5,29)^{1}$ using rat insulin as the standard (Novo Research Institute, Copenhagen, Denmark) in all control animals and chicken insulin as the standard in the transplanted animals.

Measurement of insulin in the pancreas and liver. Insulin extraction from liver and pancreatic tissue has been performed in 10 normal nondiabetic animals, in 8 diabetic rats $30 \mathrm{~d}$ after the induction of the diabetic state, and in 8 diabetic rats $15 \mathrm{~d}$ $(n=4)$ and $60 \mathrm{~d}(n=4)$ after intrahepatic transplant of pancreatic tissue from 15-d-old chicken embryos. After the acidalcohol extraction during $48 \mathrm{~h}$ at $4^{\circ} \mathrm{C}$, the insulin radioimmunoassay was performed on the supernate.

Histological and immunocytochemical investigations. The pancreas and liver of transplanted animals were fixed in Bouin's solution. Tissue sections were stained alternately by hematoxylin-eosin and indirect immunofluorescence. Tissues were stained for insulin or glucagon, and the controls included absorption of the antisera by insulin or glucagon and substitution of the serum of the first layer by sera of nonimmunized animals.

In situ vascular perfusion of the recipient's pancreas (Fig. 2). More than 18 mo after the embryonic tissue was transplanted, vascular perfusion of the isolated recipient's pancreas was performed in four cases. This was done to determine whether or not complete destruction of the B cells had been achieved

\footnotetext{
${ }^{1}$ Commissariat a l'Energie Atomique.
} 


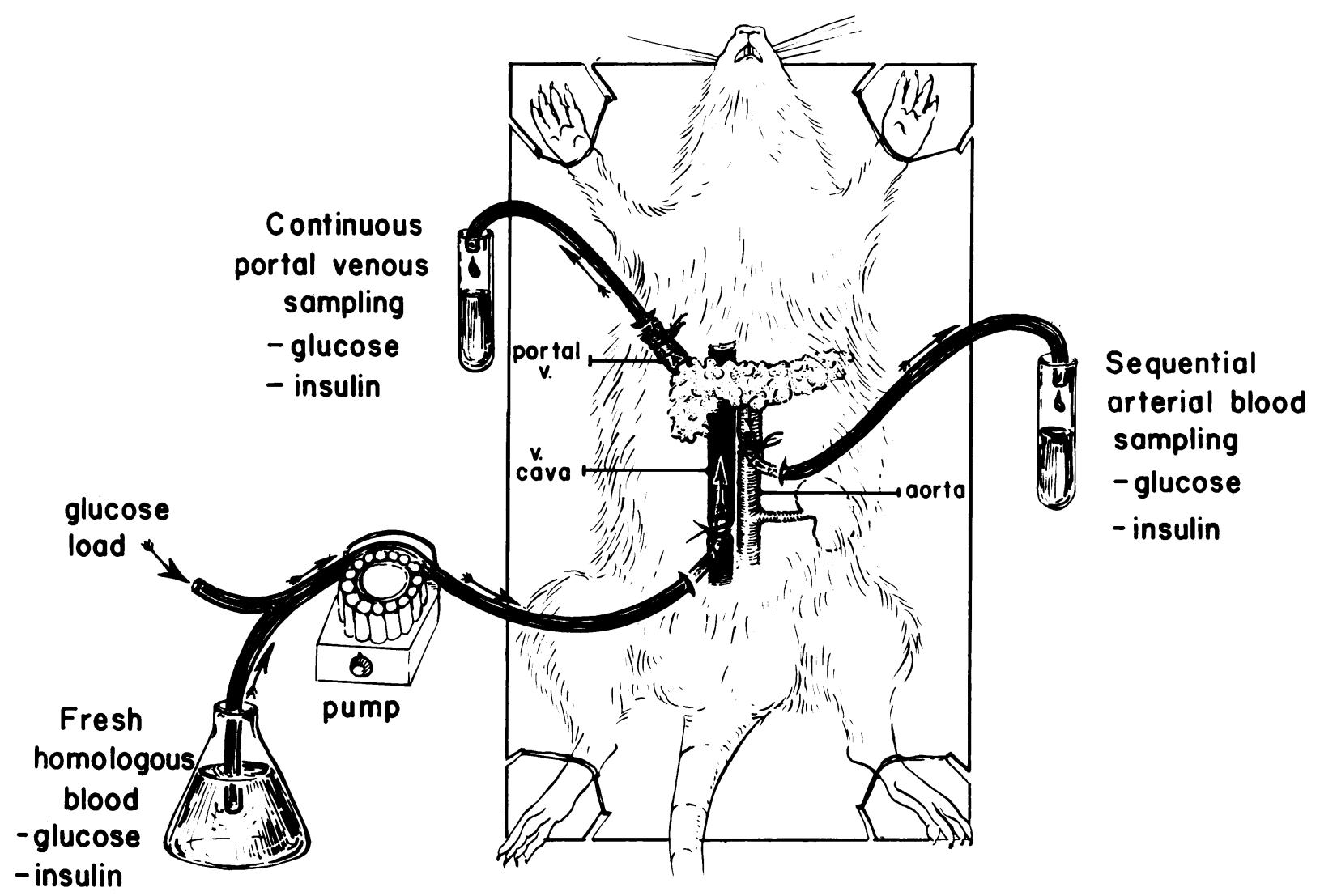

FIGURE 2 Vascular perfusion of the recipient pancreas.

and maintained in the recipients several months after administration of Streptozotocin. Similar experiments were also performed in 7 normal rats and in 10 nongrafted diabetic animals.

The in situ vascular perfusion of the rat pancreas was set up by modifying previously described procedures both in dogs and rats $(30,31)$. Through a midline vertical laparotomy the peritoneum overlying the aorta was stripped off to expose the origins of the celiac and superior mesenteric arteries. Both renal and adrenal vessels were ligated. The aorta was dissected below the renal arteries and a fine polythene heparinized catheter was introduced into the aorta. The top of the catheter was placed opposite the origin of the superior mesenteric artery. The portal vein was isolated after its junction with the superior duodenopancreatic vein, and cannulated towards its mesenteric end. Its hepatic end was ligated so that the pancreatic and mesenteric effluent could be collected. The inferior vena cava was dissected below the renal vessels, and a metallic cannula filled with heparinized physiological buffer solution was adjusted to lie just caudal to them. It was connected to a calibrated nonperistaltic pump and undiluted homologous heparinized fresh blood was injected so as to maintain a constant arterial pressure of $\cong 90-100 \mathrm{~mm} \mathrm{Hg}$. The blood collected from the portal vein was not recirculated.

A glucose load was given by additional infusion of glucose $(25 \mathrm{~g} / 100 \mathrm{ml})$ into the inferior vena cava catheter at a constant rate of $0.2 \mathrm{ml} / \mathrm{min}$ over $10 \mathrm{~min}$. Blood samples were drawn from the aortic and portal catheters and from the blood reservoir every 2-5 min. Glucose and insulin assays were performed on each sample. The output of insulin solely from the recipient's pancreas was determined by the following formula: portal insulin concentration minus aortic insulin concentration in microunits per milliliter times portal venous output in milliliters per minute. Extrapancreatic insulin output from nonpancreatic B cells can sometimes be detected when, despite complete diversion of the normal pancreatic endocrine secretion by way of the portal catheter, the aortic insulin concentration is significantly higher than that of the blood reservoir.

\section{RESULTS}

Diabetic nontreated animals (group $I, n=31$ ). The following data were obtained by pooling the results from the diabetic animals surviving $>10 \mathrm{~d}$ after the injection of Streptozotocin. The mean survival time of these animals was $27.26 \pm 2.94 \mathrm{~d}$ after induction of diabetes. The weight of these animals decreased progressively and by the 21 st $d$ it was $76.3 \pm 3.4 \%$ of their weight at induction of diabetes (Table I). The mean fasting glycemia was $2.91 \pm 0.13 \mathrm{~g} /$ liter. Nonfasting glycemia was higher than $5.87 \pm 0.17 \mathrm{~g} / \mathrm{liter}$. The output of urine averaged $92.2 \pm 2.6 \mathrm{ml} / 24 \mathrm{~h}$ and the mean urinary glucose losses was $83.7 \pm 6.08 \mathrm{~g} /$ liter or $\cong 7-9 \mathrm{~g} / \mathrm{d}$. Immunoreactive circulating levels of insulin were $2.57 \pm 0.32$ and 2.58 $\pm 0.55 \mu \mathrm{U} / \mathrm{ml}$ in the fasting and nonfasting states, respectively.

Normal animals (group $I I, n=28$ ). Rats of the same initial weight (150-200 g) were studied for more 
TABLE I

Weight Changes in the Four Experimental Groups

\begin{tabular}{|c|c|c|c|c|}
\hline & \multicolumn{4}{|c|}{ Time after induction of diabetes } \\
\hline & $0-15$ th $\mathrm{d}$ & 15 th-30th d & 30 th-60th d & $\begin{array}{l}\text { After the } \\
60 \text { th } d\end{array}$ \\
\hline $\begin{array}{l}\text { Diabetic rats } \\
\quad(\text { group } I, n=31)\end{array}$ & $\begin{array}{c}84.5 \pm 1.4 \\
n=31\end{array}$ & $\begin{array}{c}79.2 \pm 3.5 \\
n=21\end{array}$ & $\begin{array}{c}82.7 \pm 6.2 \\
n=7\end{array}$ & \\
\hline $\begin{array}{l}\text { Normal control rats } \\
\quad(\text { group II, } n=28)\end{array}$ & $109.9 \pm 1.7^{*}$ & $120.6 \pm 1.9 *$ & $129.7 \pm 1.6^{*}$ & $134.8 \pm 3.1$ \\
\hline $\begin{array}{l}\text { After transplantation of pancreas } \\
\text { from 18-d-old embryos } \\
\text { (group III, } n=10 \text { ) }\end{array}$ & $\begin{array}{c}99.1 \pm 5.0^{*} \ddagger \\
n=10\end{array}$ & $\begin{array}{c}97.3 \pm 8.0^{*} \downarrow \\
n=10\end{array}$ & $\begin{array}{c}74.4 \pm 5.1 \neq \\
n=3\end{array}$ & \\
\hline $\begin{array}{l}\text { After transplantation of pancreas } \\
\text { from } 15 \text {-d-old embryos } \\
\text { (group IV, } n=19 \text { ) }\end{array}$ & $\begin{array}{c}110.7 \pm 3.8^{*} \S \\
n=19\end{array}$ & $\begin{array}{c}120.0 \pm 6.0^{*} \S \\
n=19\end{array}$ & $\begin{array}{c}140.9 \pm 10.8^{*} \S \\
n=15\end{array}$ & $\begin{array}{c}154.0 \pm 6.0 \\
n=10\end{array}$ \\
\hline
\end{tabular}

The weight of each animal is expressed as the percentage of its initial weight at time of diabetes induction.

* Values are significantly different from those in animals in group $\mathrm{I}(P<0.05)$.

\$ Values are significantly different from those in animals in group II $(P<0.05)$.

$\S$ Values are significantly different from those in animals in group III $(P<0.05)$.

than 6 mo. All gained weight steadily as shown in Table I. After 1 mo their mean weight was about $130 \%$ of the initial value. Urine volumes were maintained at $9.85 \pm 0.14 \mathrm{ml} / 24 \mathrm{~h}$. Urine glucose excretion was negligible $(0.038 \mathrm{~g} / 24 \mathrm{~h})$. The value of nonfasting serum glucose was of $1.47 \pm 0.02 \mathrm{~g} /$ liter. Mean fasting serum glucose was $1.03 \pm 0.03 \mathrm{~g} /$ liter. Fasting serum immunoreactive insulin was $15.30 \pm 1.81 \mu \mathrm{U} / \mathrm{ml}$ and nonfasting immunoreactive insulin was $48.87 \pm 5.34 \mu \mathrm{U} / \mathrm{ml}$.

Insulin content of the chick embryo pancreas (splenic lobe). The mean weight of one splenic lobe of the chicken pancreas was $0.325 \pm 0.047 \mathrm{mg}$ at the 18 th $\mathrm{d}$ of incubation, whereas it was $0.226 \pm 0.016 \mathrm{mg}$ at the $15 \mathrm{th} \mathrm{d}$ of incubation. The insulin concentration determined at 15 and $18 \mathrm{~d}$ of incubation and expressed as milliunits per milligram wet weight (mean \pm SEM of 11 determinations) can be summarized as follows: 15th $\mathrm{d}$ : 9.55 $\pm 0.37 \mathrm{mU} / \mathrm{mg}$ wet weight; 18 th $\mathrm{d}: 8.68 \pm 0.72 \mathrm{mU} / \mathrm{mg}$ wet weight.

Effect of transplanting splenic lobes of 18-d-old embryos (group III, $n=10$ ). None of these recipients exhibited a long-term improvement of their diabetic state after transplantation. Their mean survival time was $42.1 \pm 12.4 \mathrm{~d}$ after induction of diabetes. Body weight, shown in Table I, remained significantly different from that of normal animals. Measurements of glucose and insulin are summarized in Fig. 3 and Table II, respectively. Despite a transient and significant decrease of the fasting glycemia during the lst $30 \mathrm{~d}$ after transplantation, pancreatic grafting was not of lasting value.

Effect of intrahepatic transplantation of splenic lobes of 15-d-old embryos (group IV, $n=19$ ). Among the 24 diabetic rats submitted to transplantation, 5 did not exhibit immediate improvement of their metabolic state after transplantation (nonfasting glycemia of $>4.98 \pm 0.39 \mathrm{~g} /$ liter during the 1 st $15 \mathrm{~d}$ after transplantation; urinary volume and glucose losses were not different from pretransplant values). Three of them survived $<40 \mathrm{~d}$ and two rats survived $>2$ mo but remained in a severely diabetic state. 19 rats had a significant improvement in their diabetic state after transplantation and were included in this group. These animals gained weight after transplantation and are compared to control nondiabetic animals and to diabetic nontransplanted rats in Table I. There was no significant difference between controls (group II) and transplanted rats, but in the latter the weight gain was significantly higher than in non-transplanted diabetic animals (group I), or in those grafted with endocrine tissue from 18-d-old embryos (group III). The survival time of the transplanted animals was $>180 \mathrm{~d}$ after the induction of diabetes.

Nonfasting serum glucose levels fluctuated as shown in Fig. 3. During the $2 \mathrm{wk}$ after transplantation they were significantly different from diabetic levels, and from those of normal control animals $(P<0.05)$. However, the fasting serum sugar levels progressively fell and were not different from that of control animals (Group II) by the 3rd posttransplant wk. Nonfasting glycemia was not significantly different from control animals even at the 150th posttransplant $d$.

Urine volumes were significantly reduced after transplantation but remained significantly larger than those of control animals (Table II) for at least 2 mo. Urinary glucose losses were $4.5 \pm 1.2 \mathrm{~g} /$ liter 2 mo after trans- 

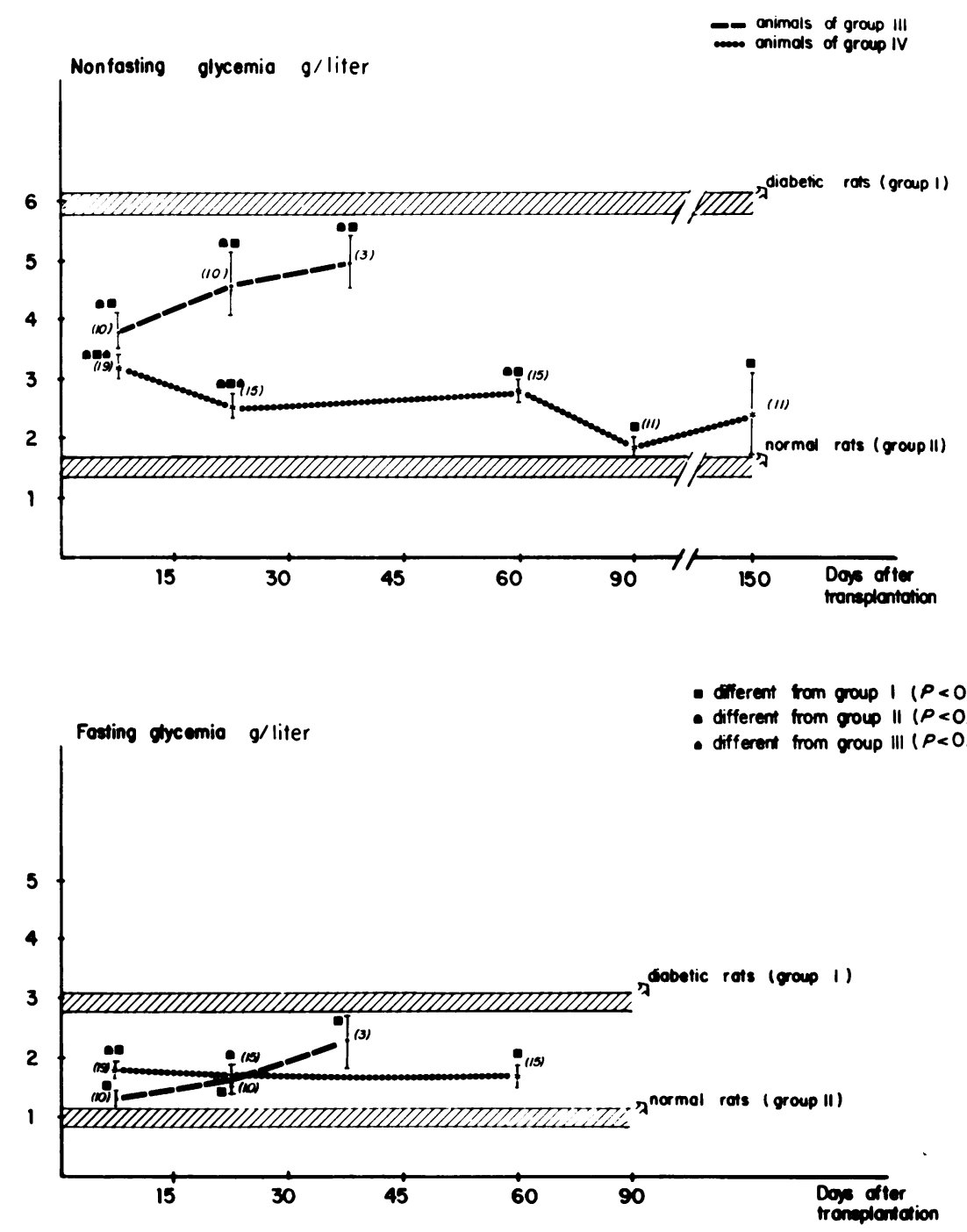

FIGURE 3 Evolution of fasting (lower graph) and nonfasting (upper graph) glycemia in rats submitted to intrahepatic transplantation of pancreas from 18-d-old embryos (group III, $n=10$ ) or 15-d-old embryos (group IV, $n=19$ ). The data were compared to those of control diabetic animals (group I, $n=31$ ) and normal rats (group II, $n=28$ ). Recipients in groups III and IV were also compared.

plantation (between 0.09 and $0.15 \mathrm{~g} / \mathrm{d}$ ). There were the usual marked daily swings of serum insulin levels ranging between 28 and $50 \mu \mathrm{U} / \mathrm{ml}$. $60 \mathrm{~d}$ after transplantation the serum insulin was significantly higher than pretransplant values.

Determination of the insulin content of the pancreas and liver. The insulin concentrations of the anterior hepatic lobe of 10 normal control (group II), 8 diabetic nontransplanted (group I), and 8 diabetic transplanted (group IV) rats are reported in Table III. 2 mo after intrahepatic transplantation of endocrine tissue of 15-dold embryos the mean \pm SEM insulin content of the liver was $4.52 \pm 2.34 \mathrm{mU} / \mathrm{g}$ wet weight tissue with a range of $11.55 \mathrm{mU} / \mathrm{g}$ wet weight tissue ( 2 mo after trans- plantation). On the other hand, the pancreatic insulin content was reduced from $>250 \mathrm{mU} / \mathrm{g}$ in normal animals to $11.90 \pm 4.54$ and $12.55 \pm 0.03 \mathrm{mU} / \mathrm{g}$ wet weight in diabetic and transplanted rats, respectively. The insulin pancreatic content was not modified after transplantation, as compared to control diabetic nontransplanted animals.

Histological examination of the pancreas and liver of the transplanted animals. Histological examinations of 15-d-old chick embryonic splenic lobe of the pancreas before (Fig. 4) and after transplantation (Figs. 5 and 6) are illustrated. 2 mo (Fig. 5) after successful transplantation despite the presence of a slight fibrotic reaction around the foreign tissue, no histological evi- 

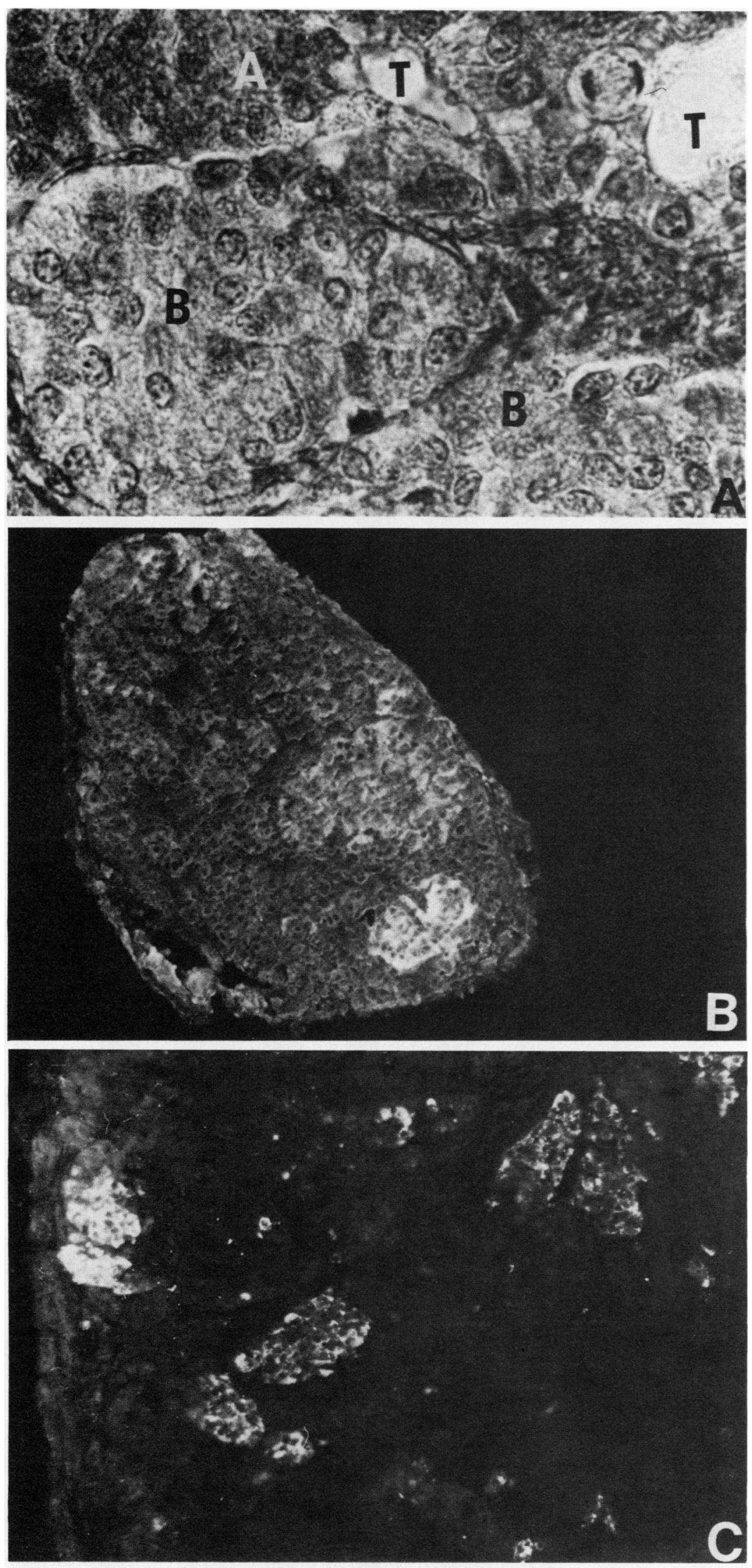
TABLE II

Changes in Urine Volume and Fed and Fasted Plasma Insulin Concentrations

\begin{tabular}{|c|c|c|c|c|}
\hline & \multicolumn{4}{|c|}{ Time after transplantation of pancreas } \\
\hline & $\begin{array}{l}\text { 1st and 2nd post- } \\
\text { transplant wk }\end{array}$ & $\begin{array}{l}\text { 3rd and 4th post- } \\
\text { transplant wk }\end{array}$ & $\begin{array}{l}\text { 60th post- } \\
\text { transplant } d\end{array}$ & $\begin{array}{l}\text { 90th post- } \\
\text { transplant d }\end{array}$ \\
\hline \multicolumn{5}{|c|}{$\begin{array}{l}\text { Urinary volume, } \\
m l / 24 h\end{array}$} \\
\hline $\begin{array}{l}\text { Animals of } \\
\text { group III }\end{array}$ & $\begin{array}{c}58.5 \pm 5.7^{*} \downarrow \\
n=10\end{array}$ & $\begin{array}{c}57.3 \pm 6.1 * \downarrow \\
n=10\end{array}$ & $\begin{array}{c}89.2 \pm 16.1^{*} \\
n=3\end{array}$ & \\
\hline $\begin{array}{l}\text { Animals of } \\
\text { group IV }\end{array}$ & $\begin{array}{c}40.9 \pm 2.8^{*} \ddagger \S \\
n=19\end{array}$ & $\begin{array}{c}36.0 \pm 3.1^{*} \ddagger \S \\
n=15\end{array}$ & $\begin{array}{c}37.0 \pm 2.7 * \$ \S \\
n=15\end{array}$ & $\begin{array}{c}10.0 \pm 1.5 \\
n=11\end{array}$ \\
\hline \multicolumn{5}{|c|}{$\begin{array}{l}\text { Fasting serum insulin } \\
\text { concentration, } \mu U / m l\end{array}$} \\
\hline $\begin{array}{l}\text { Animals of } \\
\text { group III }\end{array}$ & $\begin{array}{c}4.6 \pm 1.5^{*} \\
n=10\end{array}$ & $\begin{array}{c}15.6 \pm 6.1 \ddagger \\
n=10\end{array}$ & $\begin{array}{c}1.3 \pm 1.0^{*} \\
n=3\end{array}$ & \\
\hline $\begin{array}{l}\text { Animals of } \\
\text { group IV }\end{array}$ & $\begin{array}{c}6.1 \pm 1.1^{*} \\
n=19\end{array}$ & $\begin{array}{c}11.5 \pm 3.4 \ddagger \\
n=15\end{array}$ & $\begin{array}{c}6.6 \pm 1.6^{*} \ddagger \\
n=15\end{array}$ & \\
\hline \multicolumn{5}{|c|}{$\begin{array}{l}\text { Nonfasting serum } \\
\text { insulin concentration, } \\
\mu U / m l\end{array}$} \\
\hline $\begin{array}{l}\text { Animals of } \\
\text { group III }\end{array}$ & $\begin{array}{c}14.6 \pm 4.0 * \ddagger \\
n=10\end{array}$ & $\begin{array}{c}14.5 \pm 5.9 * \ddagger \\
n=10\end{array}$ & & \\
\hline $\begin{array}{l}\text { Animals of } \\
\text { group IV }\end{array}$ & $\begin{array}{c}39.0 \pm 4.6 \neq \S \\
n=19\end{array}$ & $\begin{array}{c}27.4 \pm 3.5^{*} \ddagger \S \\
n=15\end{array}$ & $\begin{array}{r}30.5 \pm 8.0 \ddagger \\
n=15\end{array}$ & \\
\hline
\end{tabular}

Changes in urine volume and fed and fasted plasma insulin concentrations (mean $\pm \mathrm{SEM}$ ) of diabetic rats submitted to intrahepatic transplantation of pancreas from 18-d-old embryos (group III; $n=10$ ) or 15 -d-old embryos (group IV, $n=19$ ). Statistical analysis was performed to compare the data of control diabetic animals (group I, $n=31$ ) and normal rats (group II, $n=28$ ) to those of transplanted animals. Recipients of group III and IV were also compared.

* Values are significantly different from those in animals of group II $(P<0.05)$.

\$ Values are significantly different from those in animals of group $\mathrm{I}(P<0.05)$.

$\S$ Values are significantly different from those in animals of group III at the same posttransplant time $(P<0.05)$.

dence of rejection was observed. $21 \mathrm{~d}$ after transplantation (Fig. 6) cells reacting with antiglucagon and antiinsulin serum were identified. These reacting islets are similar to those present in the nongrafted embryonic tissue (Figs. 4B and C), although some inflammatorylike cells, reacting nonspecifically with antisera, were located at the periphery of the implanted area (Fig. 6C).

No insulin-reacting cells were identified on pancreatic sections of diabetic rats with or without transplants, whereas hyperplasia of glucagon-reacting cells within the endocrine islets was commonly observed.

Functional assessment of the complete destruction of the pancreatic $B$ cells of the recipients. In Table IV the mean \pm SEM insulin output of the in situ pancreas after glucose challenge are shown. These results demonstrated the destruction and non-regeneration of functioning insulin producing cells within the pancreas of animals treated with Streptozotocin. Moreover, some results suggested that insulin was liberated in response to the glucose load somewhere else in the rat because the arterial insulin concentration was higher than that of the reservoir at the same experimental time, despite the complete diversion of the portal pancreatic effluent. However these results are only qualitative and cannot reflect quantitative aspects of insulin output from extrapancreatic sources because the methodology is inappropriate for this purpose.

\section{DISCUSSION}

This study suggests that embryonic transplants of 15-dold chick pancreas were able to significantly improve

FIGURE 4 15-d-old chick embryonic splenic lobes. (A) Histological aspect showing two islets of endocrine B cells (B), which are normally devoid of tinctorial affinity for azocarmin in contrast to the A cells (A). Two primitive tubules (T) are also visible. Original magnification, $\times 370$ (Azan staining). (B) Specific staining of glucagon islets by antiglucagon serum. Original magnification, $\times 115$. (C) Specific staining of insulin islets by antiinsulin serum. Original magnification, $\times 230$. 
TABLE III

Insulin Concentrations in the Pancreas and Liver

\begin{tabular}{|c|c|c|c|c|}
\hline & \multirow[b]{2}{*}{$\begin{array}{l}\text { Control rats } \\
n=10\end{array}$} & \multirow{2}{*}{$\begin{array}{c}\text { Diabetic rats } \\
30 \mathrm{~d} \text { after induction } \\
\text { of diabetes } \\
n=8\end{array}$} & \multicolumn{2}{|c|}{ Diabetic transplanted rats } \\
\hline & & & $\begin{array}{l}\text { 15th posttransplanted d } \\
\qquad(n=4)\end{array}$ & $\begin{array}{l}\text { 60th posttransplanted d } \\
\qquad(n=4)\end{array}$ \\
\hline $\begin{array}{l}\text { Liver, } \\
\quad m U / g \text { wet weight }\end{array}$ & $0.084 \pm 0.013$ & $0.083 \pm 0.012$ & $1.93 \pm 0.30 *$ & $4.52 \pm 2.34 * t$ \\
\hline $\begin{array}{l}\text { Caudal pancreas, } \\
\text { mU/g wet weight }\end{array}$ & $>250$ & $11.90 \pm 4.54^{*}$ & $19.22 \pm 9.14^{*}$ & $12.55 \pm 0.03^{*}$ \\
\hline
\end{tabular}

Insulin concentrations in the pancreas and liver of control nondiabetic (group II, $n=10$ ), diabetic (group I, $n=8$ ), and diabetic transplanted rats (group IV, $n=8$ ) 15 and $60 \mathrm{~d}$ after intrahepatic implantation of pancreatic tissue of 15-d-old embryos.

* Different from animals of group II.

$\ddagger$ Different from animals of group I.

for a prolonged period of time ( $18 \mathrm{mo}$ ) an experimental diabetic state in non immunosuppressed rats. Because these results were surprising, it was necessary to demonstrate that a spontaneous recovery from the diabetic state had not occurred. There are conflicting reports of spontaneous recovery from Streptozotocin diabetes. In mice, streptozotocin diabetes shows no tendency to remit (32), but damage to islet B cells in rats that receive lower doses of Streptozotocin is apparently reversible $(33,34)$. It is well known that in certain species and in man hyperglycemia seems to be a stimulus for B-cell proliferation. Arison et al. (33) reported a slight regenerative activity in mild streptozotocin diabetic rats but Magnall et al. (35) demonstrated that pancreatic insulin concentration remains similar to that of diabetic controls despite the presence of granulated B cells in the host pancreas.

Because histological or immunocytochemical investigatious are not a quantitative assessment of pancreatic destruction, the functional response of host pancreas, its insulin content, and the liver insulin content have been investigated before and after transplantation. Although the insulin content of the liver, determined both at the 15th and 60th posttransplant d was significantly different of that from control or diabetic nongrafted animals, the values obtained were unexpectedly very low, compared with the amount of endocrine tissue transplanted. The presence of a pancreatic graft cannot be considered responsible for a recovery of the recipient's pancreas, because the insulin content of the caudal pancreas of grafted animals was not modified, compared with diabetic nontreated animals. Moreover, the presence of immunoassayable insulin material within the caudal pancreas of diabetic rats, transplanted or not, was not associated with the demonstration of immunoreactive insulin cells. Hyperplasia of glucagon cells was visualized. The functional response of the recipient's pancreas tested by perfusion experiments clearly demonstrates the absence of host pancreas response to high glucose and suggests the existence in the host of a nonpancreatic source of circulating insulin.

Our results have to be considered in the light of our present knowledge about: (a) the morphological differentiation of $B$ cells in the embryonic chick pancreas along with the storage and secretion of insulin by this embryonic organ, $(b)$ the biochemical and physiological characteristics of avian insulin, and $(c)$ the tolerance of the host towards this embryonic endocrine transplant. A very sensitive immunohistological method allowed Dieterlen-Lievre and Beaupain (36) to demonstrate that in 13- to 17-d-old chick embryos numerous large insulin-containing islets were present in the splenic lobe of the pancreas. Their observations corroborate our quantitative evaluation of the insulin content of the splenic lobe of the pancreas between 12 and $20 \mathrm{~d}$ of incubation (29). Benzo and Green (37) reported that a steady state of insulin concentration was reached between the 14th and 18th d of incubation. Little is known about the insulin-releasing ability of the chick embryonic pancreas but the plasma insulin concentration has been reported to increase between 11 and $16 \mathrm{~d}$ of incubation, to remain steady through day 20 and to decrease markedly at hatching (37).

Chicken insulin is as active as crystalline beef, sheep, and pork insulin when tested in vitro in the rat diaphragm bioassay (38). These results indicate that the mammalian tissue receptor sites do not discriminate between these insulins which may vary in their amino acid sequences by at least six residues (39). Insulin release during perfusion of the whole pancreas (40), as well as during incubation of pancreatic pieces (41), is only stimulated by concentrations of glucose ranging between 500 and $700 \mathrm{mg} / 100 \mathrm{ml}$. These results were interpreted as relative glucose insensitivity of the chick as compared to the mammalian $\mathrm{B}$ cell. The relatively high insulin 


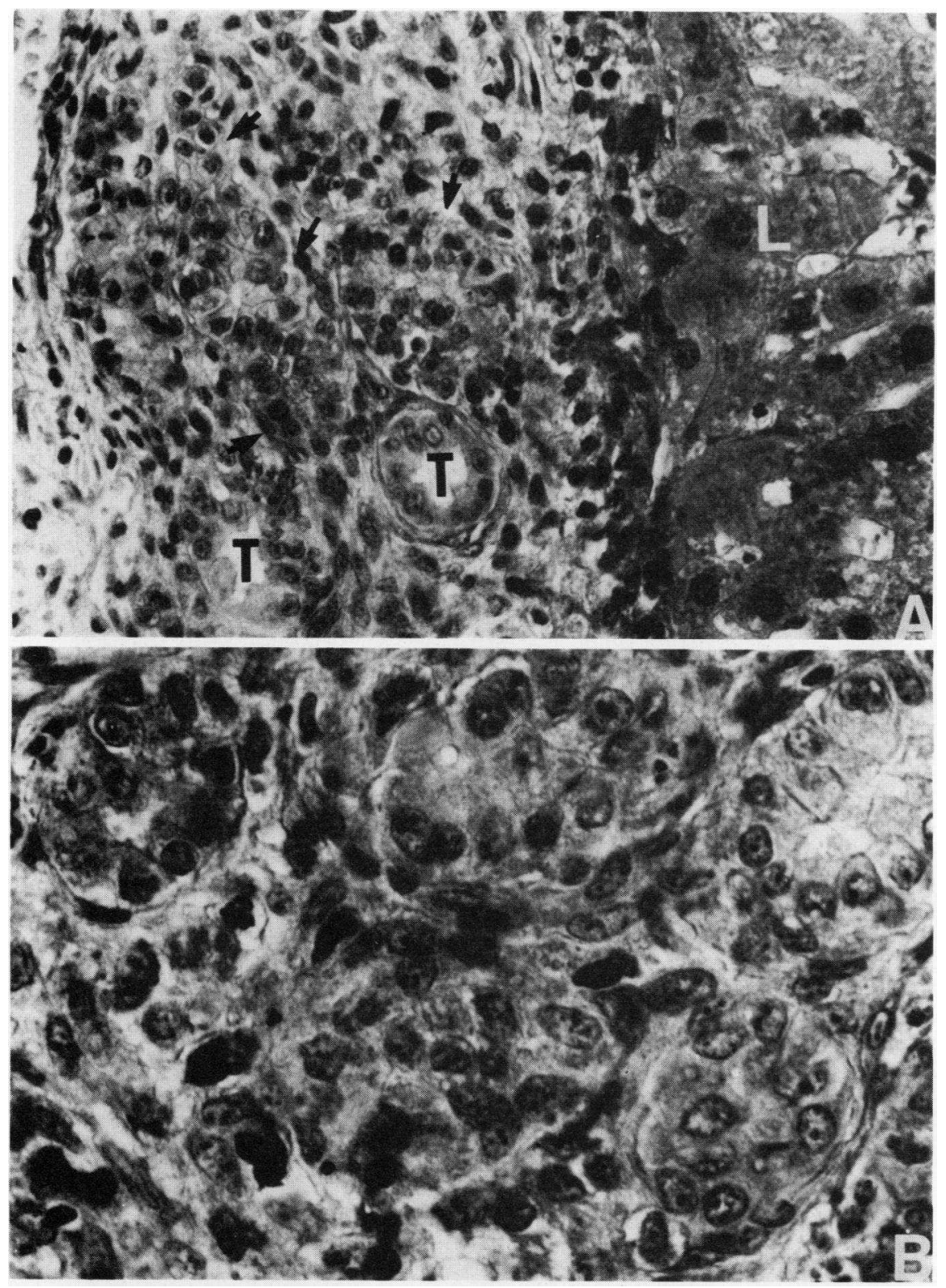

FIGURE 5 Section through a 15-d-old chick embryonic splenic lobe grafted into the liver of a diabetic rat during 2 mo. (A) The general view of the graft shows several endocrine-like islets $(\rightarrow)$ and two primitive exocrine tubules (T). Note the reduced area of fibrosis between the graft and the liver parenchymal cells (L). Original magnification, $\times 200$. (B) Details of endocrine-like and tubule-like structures. Original magnification, $\times 400$. Both figures are stained with hematoxylin-eosin.

release threshold for glucose observed in vitro helps to explain the high plasma glucose levels $(200-250$ $\mathrm{mg} / 100 \mathrm{ml}$ ) found in birds (40).

Nothing is known about the physiological regulation of insulin secretion in the chick embryo. Nevertheless, our results suggest that the embryonic transplants respond to high plasma glucose concentrations. The question arises whether this embryonic tissue can respond to lower levels of glucose because the fed blood sugar did not usually fall below $2.5 \mathrm{~g} /$ liter. Work is in progress to determine the threshold glucose concentration necessary to stimulate insulin release from a chick embryonic pancreas because the plasma glucose level of the embryo is below that of the adult 

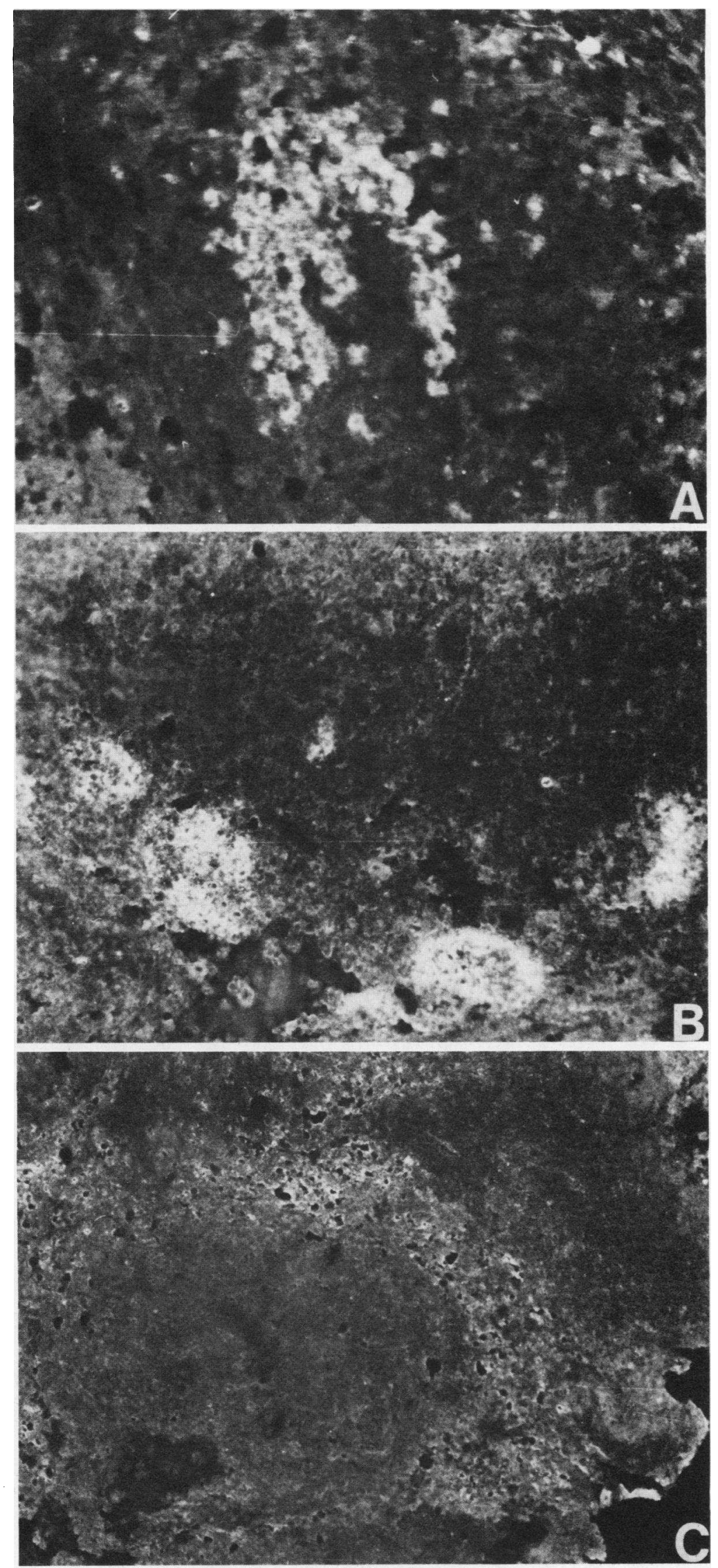
TABLE IV

Insulin Output after Glucose Load

\begin{tabular}{|c|c|c|c|c|c|}
\hline & $\begin{array}{l}\text { Before glucose } \\
\text { injection }\end{array}$ & $\begin{array}{l}\text { During glucose } \\
\text { infusion }\end{array}$ & $\begin{array}{c}20 \mathrm{~min} \text { after } \\
\text { glucose infusion }\end{array}$ & $\begin{array}{c}40 \mathrm{~min} \text { after } \\
\text { glucose infusion }\end{array}$ & $\begin{array}{c}60 \mathrm{~min} \text { after } \\
\text { glucose infusion }\end{array}$ \\
\hline & \multicolumn{5}{|c|}{$\mu U / \min$} \\
\hline $\begin{array}{l}\text { Mean values } \pm \text { SEM } \\
\text { of control rats } \\
\text { (group II, } n=7 \text { ) }\end{array}$ & $45.25 \pm 11.3$ & $77.33 \pm 13.92$ & $27.63 \pm 4.38$ & $20.59 \pm 10.61$ & $35.18 \pm 14.81$ \\
\hline $\begin{array}{l}\text { Mean values } \pm \text { SEM } \\
\text { of diabetic rats } \\
\text { (group I, } n=10 \text { ) }\end{array}$ & $2.88 \pm 1.30^{*}$ & $3.14 \pm 1.18^{*}$ & $1.54 \pm 0.79 *$ & $0.96 \pm 0.38 \sharp$ & $0.84 \pm 0.52 \ddagger$ \\
\hline $\begin{array}{l}\text { Mean values } \pm \text { SEM } \\
\text { of transplanted rats } \\
\text { (group IV, } n=4 \text { ) }\end{array}$ & $-1.92 \pm 2.25^{*}$ & $0.75 \pm 2.69 *$ & $-5.45 \pm 5.53^{*}$ & $-3.07 \pm 1.81 \ddagger$ & $4.1 \pm 6.35$ \\
\hline
\end{tabular}

Insulin output after intravenous glucose load (arterial glycemia above $4.5 \mathrm{~g} / \mathrm{liter}$ ) during vascular perfusion of the pancreas several months after transplantation (group IV). The results are compared to those obtained in nondiabetic rats (group II) and in diabetic nontransplanted rats (group I). Insulin concentration was determined every 2 to 5 min in both portal venous and aortic arterial samples. The results are expressed as pancreatic insulin output per minute before, during, and after glucose infusion as follows: (venous - arterial insulin concentration) $\times$ venous portal flow in milliliters per minute, measured every $2 \mathrm{~min}$. Insulin output in animals of group IV was never significantly different from that observed in animals of group I. No increase in the insulin output was noted during and after glucose load in animals of group IV.

Values are statistically different from control rats of group II:

$* P<0.001$.

$\ddagger P<0.05$.

at least until the 20th $\mathrm{d}$ of incubation (37). Moreover, because the most important hormone in the adult and embryonic bird is glucagon, its behavior after transplantation on diabetic hyperglucagonemic animals remains to be investigated.

A genuine "immunological unresponsiveness" is associated with intrahepatic transplantation of 15-d-old chick embryos of endocrine pancreas (42), which is not observed when 18-d-old embryo transplants are used. It is therefore interesting to review the extent of our knowledge about ontogeny of the avian immune system. Despite the fact that dissociation of the T- and Blymphocyte system was first clearly delineated in the chicken (43), the ontogeny of cellular immunity in chickens is less developed than in mammalian species. During pioneer studies (44) on the induction of tolerance by the injection of allogeneic blood into the newly hatched chick, it was found that the birds were either tolerant or unaffected.

The expression of cellular antigens on cells of different tissues is influenced by the stage of differentiation of the organism. Since the work of Burke et al. (45), Chutna and Haskova (46), Terasaki (47), and Hasek
(48), there is ample evidence that the 13- to 14-d-old chick embryo possesses transplantation antigens.

On the other hand, it has been claimed (49) that the parenchymal cells of an allograft are of low immunogenicity and that the passenger lymphoid cells carried in the allograft provide the stimulator cells that contribute the major share of allogeneic stimulation to the recipient immune system. More recently, the cell surface antigens have been divided into at least three categories (50). First, there are the classical, serologically defined antigens that are present on the surface of practically all cells or serum-defined antigens. Second, there are some antigens that are present only on restricted cell types such as B lymphocytes, macrophages, epidermal cells, and sperm. Third, there are some antigens, that if different in two individuals, lead to a mixed culture proliferative response and are named "lymphocytedefined" or "LD" antigens. Therefore, the absence or a relative immaturity of either bursal and(or) thymusdependent lymphocytes in the chick embryo transplant may account for a relative tolerance. Embryo hosts, 10 to $16 \mathrm{~d}$ of age, exhibited immunologic passiveness substantiated by the healthy growth of xenogeneic

FIGURE 6 Indirect immunofluorescence of 15-d-old chick embryonic splenic lobes grafted into the liver of a diabetic rat $21 \mathrm{~d}$ before. (A) Specific staining of glucagon cells. Original magnification, $\times 300$. (B) Specific staining of several insulin-producing islets located at the periphery of the implanted area. Original magnification, $\times 230$. (C) Control staining of the adjacent tissue section showing the absence of specific insulin-reacting cells. Original magnification, $\times 95$. 
grafts such as the Krebs ascites tumor cells of mice (51) and lymphoid and bone marrow tissues of pigeons (52). However by the 18th $\mathrm{d}$ of incubation, allogeneic cells were rejected, indicating that the fate of grafted cells differed in 14- and 18-d embryo hosts (53).

What happens at this developmental stage? In the chick embryo hemopoietic stem cells first develop in the blood islands of the yolk sac. At a later stage stem cells leave the yolk sac and migrate into the primordia of other hemopoietic tissues (54). They appear in the bursa of Fabricius on the 14th-15th d of incubation (55). However, Ewald et al. (56) found only 9.3\% of rosette forming lymphocytes in the bursa of 15-d-old embryos and none in the spleen, bone marrow, or thymus. Potworowski (57) reported that $5 \%$ of bursal lymphocytes of the 14-d-old embryo expressed B antigen and not until after hatching did such lymphocytes occur in significant number in other lymphoid tissues. Seto (58) interpreted the low humoral immune competence of neonatal chicks to an inadequate level of $\mathrm{T}$ cells as well as to a small pool of $\mathrm{B}$ cells.

Because the induction of T-regulatory cells for suppression or cytotoxicity depends on antigen-dose and on activity of the cells they regulate (59), it is conceivable that pancreatic tissue of the 15-d-old embryo is immunologically immature, lacking one or several lymphocyte subsets implicated in the afferent loop of the immune reaction. These components however may be present in an 18-d-old transplant. A more precise characterization of the immune modifications of the transplant between these two developmental stages will be the next step of our investigations.

\section{ACKNOWLEDGMENTS}

At each stage of this work the excellent technical assistance of E. Munch and F. Gosse has been greatly appreciated. Statistical treatment of the data was provided by M. Koenig. We thank Dr. G. Clendinnen for revision of the manuscript.

This work was supported by the Délégation Générale à la Recherche Scientifique et Technique (France) grant 7671461.

\section{REFERENCES}

1. Charles, M. A., W. Imagawa, P. H. Forsham, and G. M. Grodsky. 1976. Islet transplantation into rat liver: in vitro secretion of insulin from the isolated perfused liver and in vivo glucagon suppression. Endocrinology. 98: 738-742.

2. Ballinger, W. F., and P. E. Lacy. 1972. Transplantation of intact pancreatic islets in rats. Surgery (St. Louis). 72: $175-186$.

3. Steffes, M. W., D. E. R. Sutherland, M. S. Mayer, R. J. Leonard, J. S. Najarian, and D. M. Brown. 1975. Plasma insulin and glucose levels in diabetic rats prior to and following islet transplantation. J. Lab. Clin. Med. 85: 75-81.

4. Kemp, C. B., M. J. Knight, D. W. Scharp, W. F. Ballinger, and P. E. Lacy. 1973. Effect of transplantation site on the results of pancreatic islet isografts in diabetic rats. Diabetologia. 9: 486-491.
5. Eloy, R., M. Kedinger, J. C. Garaud, K. Haffen, J. F. Launay, A. J. Moody, G. Clendinnen, and J. F. Grenier. 1977. Intrahepatic transplantation of pancreatic islets in rat. Horm. Metab. Res. 9: 40-46.

6. Finch, D. R. A., and P. J. Morris. 1976. Passive enhancement of isolated pancreatic islet allografts. Transplantation (Baltimore). 22: 508-512.

7. Reckard, C. R., M. M. Ziegler, and C. F. Barker. 1973. Physiological and immunological consequences of transplanting isolated pancreatic islets. Surgery (St. Louis). 74: 91-99.

8. Nelken, D., E. A. Friedman, S. I. Morse, and M. M. Beyer. 1977. Islet of Langerhans allotransplantation in the rat. Transplant. Proc. 9: 333-336.

9. Scharp, D. W., C. B. Kemp, M. J. Knight, J. J. Murphy, W. T. Newton, W. F. Ballinger, and P. E. Lacy. 1974. Long-term results of portal vein islet isografts and allografts in the treatment of streptozotocin induced diabetes. Diabetes. 23(Suppl. 1): 359. (Abstr.)

10. Nelken, D., S. I. Morse, M. M. Beyer, and E. A. Friedman. 1976. Prolonged survival of allotransplanted islet of Langerhans cells in the rat. Transplantation (Baltimore). 22: 74-75.

11. Kedinger, M., K. Haffen, J. F. Grenier, and R. Eloy. 1977. In vitro culture reduces the antigenicity of pancreatic endocrine islets. Nature (Lond.). 270: 736-738.

12. Sutherland, D. E. R., M. W. Steffes, G. E. Bauer, D. McManus, B. Noe, and J. S. Najarian. 1974. Isolation of human and porcine islets of Langerhans and transplantation in pigs. J. Surg. Res. 16: 102-111.

13. Browning, H., and P. Resnick. 1952. Homologous and heterologous transplantation of pancreatic tissue in normal and diabetic mice. Yale J. Biol. Med. 24: 141-152.

14. Heslop, B. F. 1969. Maturation of histocompatibility antigens and host reactivity in the rat. Transplant. Proc. 1: 560-563.

15. Barker, C. F. 1975. Transplantation of the islets of Langerhans and the histocompatibility of endocrine tissue. Diabetes. 24: 766-775.

16. Hegre, O. D., R. J. Leonard, J. D. Rusin, and A. Lazarow. 1976. Transplantation of the fetal rat pancreas: quantitative morphological analysis of islet tissue growth. Anat. Rec. 185: 209-222.

17. Brown, J., I. G. Molnar, W. Clark, and Y. Mullen. 1974. Control of experimental diabetes mellitus in rats by transplantation of fetal pancreases. Science (Wash. D. C.). 184: 1377-1379.

18. Mullen, Y. S., W. R. Clark, G. Molnar, and J. Brown. 1977. Complete reversal of experimental diabetes mellitus in rats by a single fetal pancreas. Science (Wash. D. C.). 195: $68-70$.

19. Lazarow, A., L. J. Wells, A. M. Carpenter, O. D. Hegre, R. J. Leonard, and R. C. McEvoy. 1973. Islet differentiation, organ culture, and transplantation. Diabetes. 22: 877-912.

20. Gonet, A. E., and A. E. Renold. 1965. Homografting of fetal rat pancreas. Diabetologia. 1: 91-96.

21. Obando, M., A. Peale, J. Noval, N. Rao, K. Change, R. M. Reichle, and F. Reichle. 1975. Survival of syngeneic and allogeneic pancreatic transplants in non-immunosuppressed rats. Diabetes. 24: 420. (Abstr.)

22. Reemtsma, K. 1971. Heterotransplantation: theoretical considerations. Transplant. Proc. 3: 49-52.

23. Weber, C., R. Weil, R. McIntosh, H. Hogle, G. Warden, and K. Reemtsma. 1975. Xenotransplantation of piscine islets into hyperglycemic rats. Surgery (St. Louis). 77: 208-215.

24. Weber, C., A. Zatriqi, R. Weil, R. McIntosh, M. A. Hardy, 
and K. Reemtsma. 1976. Pancreatic islet isografts, allografts and xenografts: comparison of morphology and function. Surgery (St. Louis). 79: 144-151.

25. Eloy, R., S. Vuitton, J. P. Vaultier, A. Pousse, and J. F. Grenier. 1976. Decreased graft versus host reaction after intrahepatic lymphoid tissue implantation. Cell. Immunol. 21: $236-242$.

26. Vuitton, D., R. Eloy, G. Coumaros, and J. F. Grenier. 1977. Effect of partial hepatectomy on the graft versus host reaction after intrahepatic lymphoid tissue implantation. Cell. Immunol. 28: 51-58.

27. Vuitton, D., R. Eloy, G. Clendinnen, and J. F. Grenier. 1977. Role of Kupffer cells and suppressor T-cells in the graft versus host reaction after intrahepatic lymphoid tissue implantation. Cell. Immunol. 34: 138-145.

28. Kedinger, M., K. Haffen, F. Dieterlen-Lievre, and A. Moody. 1972. Données quantitatives sur la teneur en insuline du pancréas embryonnaire de poulet. $C$. $R$. Hebd. Seances Acad. Sci. 275: 2065-2068.

29. Heding, L. G. 1966. A simplified insulin radioimmunoassay method. In Conference on Problems Connected with the Preparation and Use of Labelled Proteins in Tracer Studies. Donato Ed., Pisa, Italy. 345-351.

30. Eloy, R., J. Kachelhoffer, A. Pousse, J. Dauchel, and J. F. Grenier. 1974. Ex vivo vascular perfusion of the isolated canine pancreas. Experimental procedure, haemodynamic data and experimental applications. Eur. Surg. Res. 6: 341-353.

31. Eloy, R., F. Raul, A. Pousse, R. Mirhom, A. Ananna, and J. F. Grenier. 1977. Ex vivo vascular perfusion of the isolated rat small bowel. Eur. Surg. Res. 9: 96-112.

32. Rerup, C. C., and F. Tarding. 1969. Streptozotocin and alloxan diabetes in mice. Eur. J. Pharmacol. 7: 89-96.

33. Arison, R. N., E. I. Ciaccio, M. S. Glitzer, J. A. Cassaro, and M. P. Pruss. 1967. Light and electron microscopy of lesions in rats rendered diabetic with streptozotocin. Diabetes. 16: 51-56.

34. Junod, A., A. E. Lambert, L. Orci, R. Pictet, and A. E. Gonet. 1967. Studies of diabetogenic action of streptozotocin. Proc. Soc. Exp. Biol. Med. 126: 201-205.

35. Magnall, Y., A. Smythe, D. N. Slater, G. R. Milner, R. D. G. Milner, C. B. Taylor, and M. Fox. 1977. Neonatal islet cell transplantation in the diabetic rat: effect on hepatic enzyme activity and glucose homeostasis. J. Endocrinol. 74: $231-241$.

36. Dieterlen-Lievre, F., and D. Beaupain. 1974. Etude immunocytologique de la différenciation du pancréas endocrine de poulet. I. Ilots à Insuline. Gen. Comp. Endocrinol. 22: 62-69.

37. Benzo, C. A., and T. D. Green. 1974. Functional differentiation of the chick endocrine pancreas: insulin storage and secretion. Anat. Rec. 180: 491-496.

38. Hazelwood, R. L., J. R. Kimmel, and H. G. Pollock. 1968. Biological characterization of chicken insulin activity in rats and domestic fowl. Endocrinology. 83: $1331-1336$.

39. Kimmel, J. R., H. G. Pollock, and R. L. Hazelwood. 1968. Isolation and characterization of chicken insulin. Endocrinology. 83: 1323-1330.

40. King, D. L., and R. L. Hazelwood. 1976. Regulation of avian insulin secretion by isolated perfused chicken pancreas. Am. J. Physiol. 231: 1830-1839.

41. Naber, S. P., and R. L. Hazelwood. 1977. In vitro insulin release from chicken pancreas. Gen. Comp. Endocrinol. 32: 495-504.

42. Brent, L. 1975. Introduction to the symposium on tolerance and enhancement. Transplant. Proc. 7: 337-340.

43. Cooper, M. D., R. A. Peterson, M. A. South, and R. A. Good. 1966. The functions of the thymus system and the Bursa system in the chicken. J. Exp. Med. 127: 75-102.

44. Billingham, R. E., L. Brent, and P. B. Medawar. 1956. Quantitative studies on tissue transplantation immunity. III. Activity acquired tolerance. Philos. Trans. R. Soc. Lond. B Biol. Sci. 239: 357-414.

45. Burke, V., N. P. Sullivan, H. Peterson, and R. Weed. 1944. Ontogenic change in antigenic specificity of the organs in the chick. J. Infect. Dis. 74: 225-233.

46. Chutna, J., and V. Haskova. 1959. Antigenicity of embryonic tissues in homotransplantation. Folia Biol. (Prague). 5: $85-88$.

47. Terasaki, P. I. 1959. Tolerance of skin grafts produced by various adult cells, soluble extracts and embryonic cells. J. Embryol. Exp. Morphol. 7: 400-416.

48. Hasek, M. 1960. Homotransplantation antigenicity of embryonic tissues. Folia. Biol. (Prague). 6: 54-55.

49. Lafferty, K. J., I. S. Misko, and M. A. Cooley. 1974. Allogeneic stimulation modulates the in vitro response of T-cells to transplantation antigen. Nature (Lond.). 249: 275-276.

50. Bach, F. H., M. L. Bach, and P. M. Sowdel. 1976. Differential function of major histocompatibility complex antigens in T-lymphocyte activation. Nature (Lond.). 259: 273-281.

51. Green, H., and A. L. Lorincz. 1957. The role of natural antibody in the rejection of mouse tumour cells by the chick embryo. J. Exp. Med. 106: 111-125.

52. Lafferty, K. J., and M. A. S. Jones. 1969. Reactions of the graft versus host (GVH) type. Aust. J. Exp. Biol. Med. Sci. 47: 17-54.

53. Seto, F. 1971. Allograft reactivity in chick embryos. $J$. Exp. Zool. 177: 343-352.

54. Moore, M. A. S., and J. J. T. Owen. 1963. Chromosome marker studies on the development of the haemopoietic system in the chick embryo. Nature (Lond.). 208: 956.

55. Ackerman, G. A., and R. A. Knouff. 1964. Lymphocytopoietic activity in the Bursa of Fabricius In The Thymus in Immunobiology. R. A. Good and A. E. Gabrielsen, editors. Harper \& Row, Publishers, Inc., New York. 123-146.

56. Ewald, S., L. Freedman, and B. G. Sanders. 1976. E-A Rosette forming lymphoid cells: distribution as to cell types and organs from chicken of different developmental stages. Cell. Immunol. 23: 158-170.

57. Potworowski, E. F. 1972. T and B lymphocytes organ and age distribution in the chicken. Immunology. 23: 199-204.

58. Seto, F. 1975. Enhancement of chicken hemagglutinin response by thymocytes. Exp. Hematol. (Copenh.). 3: 319-326.

59. Eardley, D. D., M. O. Staskawicz, and R. K. Gershon. 1976. Suppressor cells: dependence on assay conditions for functional activity. J. Exp. Med. 143: 1211-1219. 